\title{
Review \\ Hsp100 Molecular Chaperone ClpB and Its Role in Virulence of Bacterial Pathogens
}

\author{
Sabina Kędzierska-Mieszkowska ${ }^{1, *(1)}$ and Michal Zolkiewski ${ }^{2}$ \\ 1 Department of General and Medical Biochemistry, Faculty of Biology, University of Gdańsk, \\ 80-308 Gdańsk, Poland \\ 2 Department of Biochemistry and Molecular Biophysics, Kansas State University, Manhattan, KS 66506, USA; \\ michalz@ksu.edu \\ * Correspondence: sabina.kedzierska-mieszkowska@ug.edu.pl; Tel./Fax: +48-58-5236064
}

Citation: Kedzierska-Mieszkowska, S.; Zolkiewski, M. Hsp100 Molecular Chaperone ClpB and Its Role in Virulence of Bacterial Pathogens. Int. J. Mol. Sci. 2021, 22, 5319. https:// doi.org/10.3390/ijms22105319

Academic Editors: Antonella Marino Gammazza and Celeste Caruso Bavisotto

Received: 28 April 2021

Accepted: 15 May 2021

Published: 18 May 2021

Publisher's Note: MDPI stays neutral with regard to jurisdictional claims in published maps and institutional affiliations.

Copyright: (c) 2021 by the authors. Licensee MDPI, Basel, Switzerland. This article is an open access article distributed under the terms and conditions of the Creative Commons Attribution (CC BY) license (https:// creativecommons.org/licenses/by/ $4.0 /)$.

\begin{abstract}
This review focuses on the molecular chaperone ClpB that belongs to the Hsp100/Clp subfamily of the AAA + ATPases and its biological function in selected bacterial pathogens, causing a variety of human infectious diseases, including zoonoses. It has been established that $\mathrm{ClpB}$ disaggregates and reactivates aggregated cellular proteins. It has been postulated that ClpB's protein disaggregation activity supports the survival of pathogenic bacteria under host-induced stresses (e.g., high temperature and oxidative stress), which allows them to rapidly adapt to the human host and establish infection. Interestingly, ClpB may also perform other functions in pathogenic bacteria, which are required for their virulence. Since $\mathrm{ClpB}$ is not found in human cells, this chaperone emerges as an attractive target for novel antimicrobial therapies in combating bacterial infections.
\end{abstract}

Keywords: bacteria; $\mathrm{ClpB}$; human; infection; molecular chaperone; pathogen; virulence

\section{Introduction}

Bacteria are one of the epidemiological agents that can cause infectious diseases in humans. It is estimated that approximately $10 \%$ of the known infectious agents are bacteria [1]. However, it should be emphasized that the vast majority of bacteria are not harmful to humans and some of them are beneficial, such as intestinal bacteria which facilitate food digestion in the human gastrointestinal tract and are involved in the production of vitamins necessary for human physiology. Besides, bacteria play an important role in maintaining the ecological balance in the environment they occupy. Thus, only a fraction of bacteria is pathogenic, and causes diseases in humans and animals. A disease manifestation is a consequence of the bacteria prevailing over the defenses of a mammalian immune system. Diseases caused by pathogenic bacteria are as diverse as the bacteria themselves and include pneumonia, food- and water-borne infections, wound and bloodstream infections (known as septicemia or sepsis), or sexually transmitted diseases, such as gonorrhea and chlamydiosis. Bacterial infectious diseases have a very significant impact on public health [2]. Notably, lower respiratory infections, infectious diarrhea, and tuberculosis, caused by bacterial pathogens, are among the top causes of human mortality in the world [3]. Some bacteria are responsible for zoonotic infections which can be transmitted from animals to humans via direct or indirect contacts, sometimes also by an invertebrate vector. Importantly, bacterial zoonoses cause millions of human deaths every year, which has a significant impact on global public health and economies worldwide [4]. Bacterial zoonoses also cause major losses in livestock and impact the farming industry [5]. Farm animals are often reservoirs of zoonotic pathogens $[4,6]$. Therefore, a "One Health" approach to both medical and veterinary care, promoted by the U.S. Centers for Disease Control and Prevention, is essential for controlling the spread of zoonotic bacterial diseases. 
Understanding how bacterial infections spread and how pathogenic bacteria outsmart the host's defenses is crucial to controlling all bacterial diseases. During the infection process, an intense battle for survival takes place between an invading pathogen and the human body. The outcome of this battle depends on responses from both the pathogen and its host. In response to a bacterial intruder, a human host activates its defense and protective mechanisms, including the innate and the adaptive immune systems, which play a critical role in protection against a broad variety of pathogens, including bacteria. These two systems are sequentially activated during infection and work together to fight the invaders and destroy the initial infection [7]. In turn, pathogenic bacteria have evolved diverse strategies of interacting with the human host and rapid adaptation to new environmental conditions, including elevated temperature or oxidative stress, which are associated with the host's immune responses. Thanks to these strategies, a bacterial intruder can establish itself within an infected host, i.e., it can survive, replicate and spread inside the human body, leading to a disease manifestation. Pathogenic bacteria use a number of virulence mechanisms and factors as effective weapons in subverting the human host and turning the host's cellular processes to their advantage.

The molecular chaperone $\mathrm{ClpB}$ which belongs to the Hsp100/Clp subfamily of the AAA+ ATPases (ATPases associated with diverse cellular activities) is one of the factors which can enhance bacterial survival in the host during infection. Hsp100 chaperones are present in bacteria, protozoa, fungi, and plants, but not in animals and humans. The aim of this review is to discuss the current understanding of the role of ClpB in selected pathogenic bacteria and its importance during bacterial infections in humans. Importantly, since $\mathrm{ClpB}$ is not found in human cells, this chaperone becomes a promising target for novel antibacterial strategies, which is particularly important nowadays due to an increasing rate of developing antibiotic resistance among pathogenic bacteria, an alarming problem for global public health $[8,9]$.

\section{AAA+ Chaperone ClpB: Its Structure, Function and Mechanism of Action}

Bacterial ClpB and its yeast homolog, Hsp104 are the best-studied members of the Hsp100 chaperone family [10,11]. ClpB is found in the vast majority of bacteria with the exception of distinct bacterial species, such as the Gram positive Bacillus subtilis [12,13]. This year marks three decades since $\mathrm{ClpB}$ was first identified as a heat shock protein necessary for the optimal growth and survival of E. coli at high temperature and thus required for the thermotolerance of this bacterium [14]. Unlike many other Clp family members that form complexes with peptidase subunits and participate in protein degradation, $\mathrm{ClpB}$ cooperates with the DnaK chaperone system to solubilize and reactivate aggregated proteins accumulating in bacteria under stress conditions [15-18]. ClpB can remodel some protein substrates without the DnaK assistance, but cooperation of ClpB and DnaK produces the most efficient disaggregation [19-21]. Interestingly, the ClpB-DnaK cooperation in protein disaggregation is species-specific, i.e., $\mathrm{ClpB}$ efficiently cooperates only with $\mathrm{DnaK}$ from the same microorganism [22-24].

Like other Hsp100 family members, $\mathrm{ClpB}$ forms ring-shaped hexamers in the presence of ATP [25-28] with a narrow central channel (pore), wide enough to accommodate extended unfolded polypeptides (Figure 1). Each protomer of ClpB consists of multiple domains: N-terminal domain (NTD), two ATP-binding modules, i.e., nucleotide-binding domain 1 (NBD-1) and nucleotide-binding domain 2 (NBD-2) and a unique coiled-coil middle domain (MD) inserted at the end of NBD-1 (Figure 1A). Each NBD domain contains all the characteristic and highly conserved motifs of AAA+ ATPases, namely Walker A, Walker B, arginine finger, sensor- 1 , and sensor-2 (Figure $1 \mathrm{~A}$ ). The NTD of $\mathrm{ClpB}$ is responsible for the recognition and binding of protein substrates. NBDs generate energy from ATP for polypeptide translocation through the $\mathrm{ClpB}$ channel. The MD mediates the interactions with DnaK that are required for bacterial thermotolerance and efficient protein disaggregation $[23,24,29]$ and is also involved in coordinating the communication between NBDs [19]. Of note, the presence of the coiled-coil MD distinguishes ClpB from such Hsp100/Clp 
proteins as ClpA, ClpX or HslU that are associated with a peptidase (ClpP or HslV) and do not display disaggregase activity.

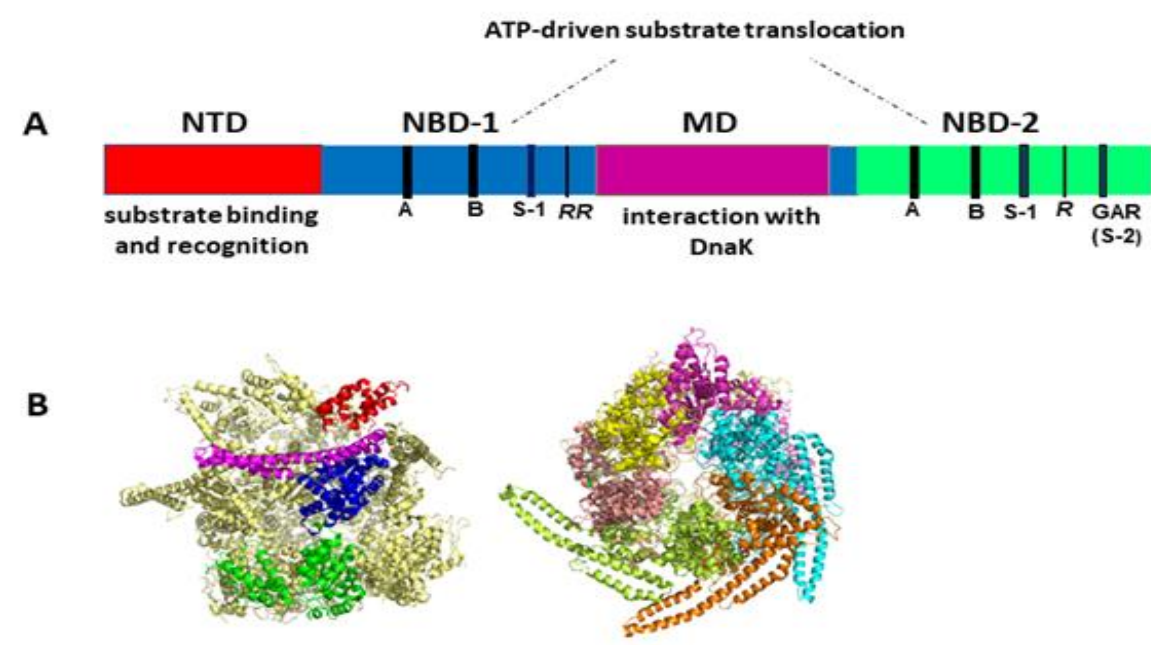

Figure 1. (A) Structural organization of the $\mathrm{ClpB}$ monomer. Four domains are indicated: $\mathrm{N}$-terminal domain (NTD), two nucleotide-binding domains (NBD-1 and NBD-2), and middle domain (MD). Each NBD contains the characteristic AAA+ motifs: Walker A (GX $\left.{ }_{4} \mathrm{GKT} / \mathrm{S}\right)(\mathrm{A})$, Walker B ( $\left.\mathrm{Hy}_{2} \mathrm{DE}\right)$ (B), sensor-1 (S-1), sensor-2 (S-2, GAR), and the arginine fingers (R). (B) Cryo-EM structure of hexameric Hsp104 from S. cerevisiae in the closed conformation (PDB entry 6N8T) [30]. Left panel: side view with the structural domains indicated for one Hsp104 subunit: NTD (red), NBD-1 (blue), MD (magenta), and NBD-2 (green). Right panel: top view with each subunit shown in a different color. The substrate-processing channel is visible at the center of the structure. Three out of six MDs were resolved in this cryo-EM image analysis, which highlights the highly dynamic properties and structural asymmetry of the hexameric complex. Images generated using PyMol 1.3 (Schrödinger LLC, www.pymol.com accessed on 2010).

Elegant studies of Bukau's group demonstrated that protein disaggregation mediated by ClpB is linked to the ATP hydrolysis-coupled substrate translocation through the central channel [31]. Recent advances in high-resolution cryo-electron microscopy and single-molecule force spectroscopy provided critical insights into the mechanism of $\mathrm{ClpB}$ activity. Most significantly, recent cryo-EM image reconstructions revealed that the subunits of hexameric ClpB/Hsp104 (Figure 1B) are arranged in a spiral configuration and undergo dynamic conformational rearrangements which support ratcheting of substrates through the central channel [30,32-34]. Optical tweezer experiments demonstrated that $\mathrm{ClpB}$ is a powerful source of a mechanical force capable of extracting polypeptides from aggregated particles and possibly acting upon surface-exposed loops (Figure 2) [35]. In contrast to a directional force generation by $\mathrm{ClpB}$, DnaK and other Hsp70 chaperones modulate the conformation of their substrates by applying "entropic pulling" and stochastic interactions [36,37]. 


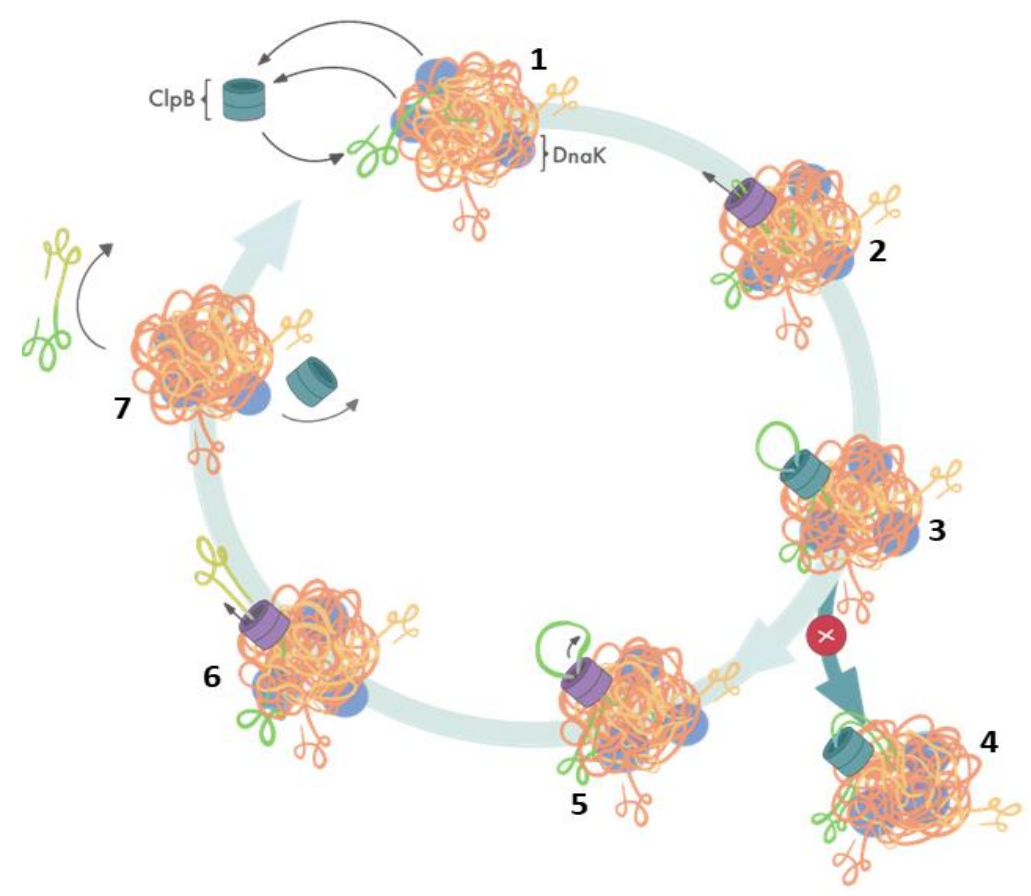

Figure 2. Cooperation of $\mathrm{ClpB}$ and DnaK during aggregate reactivation based on ref. [35]. (1) The aggregate-bound $\mathrm{DnaK}$ recruits $\mathrm{ClpB}$ to a protein aggregate and exposes $\mathrm{ClpB}$-accessible fragments of the aggregate; (2) ClpB initiates substrate translocation from an exposed polypeptide loop; (3) stably folded domains can become obstacles for $\mathrm{ClpB}$-mediated polypeptide extraction; (4) resistance during the translocation stalls $\mathrm{ClpB}$-mediated disaggregation; (5) switching to single-strand translocation can release stalled $\mathrm{ClpB}$; (6) extracted unfolded polypeptide exits the ClpB channel; (7) extracted polypeptide refolds while $\mathrm{ClpB}$ can engage in another polypeptide extraction cycle.

In summary, $\mathrm{ClpB}$ is a pivotal component of protein quality control which maintains protein homeostasis (proteostasis) in bacterial cells and supports their survival under environmental stresses by mediating the reactivation of protein aggregates. Due to their unique protein disaggregation activity, $\mathrm{ClpB}$ and its yeast ortholog Hsp104 were postulated to become tools in the development of novel therapies for human protein aggregation diseases, such as Alzheimer's disease, Parkinson's disease, or Huntington's disease. However, no $\mathrm{ClpB} / \mathrm{Hsp} 104$ orthologs were found in the human and animal proteomes [38], which created an opportunity to explore the potential of this chaperone as a novel antimicrobial target.

\section{The Role of ClpB in Bacterial Pathogens}

During the past few decades, a number of studies revealed the ClpB involvement in the virulence of many bacterial pathogens, but a specific function of $\mathrm{ClpB}$ during infection remains to be fully elucidated. Below, we discuss the role of $\mathrm{ClpB}$ in the group of bacterial pathogens where that chaperone's function was investigated (Table 1). Included among those pathogens are both Gram-positive and Gram-negative bacteria, gastrointestinal pathogens that must contend with diverse physical and chemical stresses, and also bacteria that cause animal-to-human zoonotic infections, such as leptospirosis, ehrlichiosis or fmia. Among the bacteria discussed below, Ehrlichia chaffeeensis and Mycoplasma pneumoniae are obligate intracellular pathogens that exclusively grow and replicate inside the host cells, while others are facultative pathogens, capable of proliferation both inside the host cells and in environmental niches. 
Table 1. Selected bacterial pathogens and the associated diseases in humans and animals [1,39-47].

\begin{tabular}{|c|c|c|}
\hline Bacterial Species & Disease & Transmission \\
\hline $\begin{array}{c}\text { Ehrlichia chaffeensis * } \\
\text { (Gram-negative Rickettsia bacterium) }\end{array}$ & human monocytic ehrlichiosis (HME) & $\begin{array}{l}\text { zoonosis transmitted through an } \\
\text { infected tick }\end{array}$ \\
\hline $\begin{array}{l}\text { Enterococcus faecalis } \\
\text { (Gram-positive cocci) }\end{array}$ & $\begin{array}{l}\text { bacteremia, endocarditis, } \\
\text { intra-abdominal, pelvic and soft tissue } \\
\text { infections, and urinary tract infections }\end{array}$ & $\begin{array}{l}\text { transmission via a physical contact } \\
\text { (person-person) or a contact with } \\
\text { contaminated surfaces }\end{array}$ \\
\hline $\begin{array}{c}\text { Francisella tularensis } \\
\text { (Gram-negative coccobacillus) }\end{array}$ & tularemia (also known as a rabbit fever) & $\begin{array}{l}\text { zoonosis transmitted to humans in } \\
\text { numerous ways, including ticks, deerfly } \\
\text { bites, direct handling of infected tissues, } \\
\text { ingestion of contaminated water or } \\
\text { tissues, or inhalation of } \\
\text { infective materials }\end{array}$ \\
\hline $\begin{array}{c}\text { Leptospira interrogans } \\
\text { (Gram-negative spirochaete) }\end{array}$ & $\begin{array}{l}\text { leptospirosis in mammals, } \\
\text { including humans }\end{array}$ & $\begin{array}{l}\text { zoonosis (wild and domestic animals are } \\
\text { a main source of this pathogen) } \\
\text { transmitted mainly through urine of } \\
\text { infected animals, contact with a } \\
\text { urine-contaminated environment, i.e., } \\
\text { water or moist soil }\end{array}$ \\
\hline
\end{tabular}

food-borne infections; listeriosis of pregnancy; neonatal listeriosis; clinical syndromes associated with listeriosis: meningoencephalitis, meningitis, septicemia, spontaneous abortions, stillbirth, premature labor, and neonatal disease

Listeria monocytogenes
(Gram-positive rod)

Mycobacterium tuberculosis (neither Gram-positive nor Gram-negative bacterium) infection occurs through consumption of contaminated food (unpasteurized milk, soft cheeses, vegetables and some meat products), transmission is possible from mother to fetus and from mother to child during birth

transmission through airborne particles called droplet nuclei generated by a sick person coughing, sneezing, shouting, or singing

transmission through droplets generated by an infected person coughing or sneezing

Mycoplasma pneumoniae * (Gram-negative)

acute and chronic respiratory diseases; pneumonia

periodontal diseases, chronic periodontitis, systemic diseases, including heart disease, stroke, and diabetes mellitus as well as preterm delivery of low birth-weight infants

colonization of the mouth (Gram-negative rod)

wide spectrum of infections from

Staphylococcus aureus (Gram-positive) superficial wound infections, Staph food poisoning to life threatening septicemia and toxic shock syndrome;

skin and mucous membrane colonization; transmission through direct contact (person-person)

zoonosis transmitted through contact with infected animals, contaminated water, and the environment; food-borne infections

* Obligate intracellular pathogens.

In Staphylococcus aureus, Francisella tularensis, and Porphyromonas gingivalis, ClpB is required for survival under stress conditions and intracellular proliferation in in vitro and in vivo models $[39,40,48,49]$. Interestingly, recent experiments utilizing $F$. tularensis subspecies holarctica and tularensis demonstrated that $\mathrm{ClpB}$ performs multiple functions in these subspecies and its activity is important not only for the intracellular replication of these pathogens, but also for type VI secretion system (T6SS), which is essential for their virulence. Of note, T6SS in bacteria requires the assistance of ATPases, typically ClpV and 
IcmF. However, F. tularensis lacks both $\mathrm{ClpV}$ and the Walker A motif in IcmF (which is crucial for the ATPase activity), but nevertheless exhibits a functional T6SS. It has been demonstrated that in the absence of ClpB, T6SS in F. tularensis is severely impaired as compared to the wild-type strain [49]. Therefore, it was postulated that ClpB compensates for the $\mathrm{ClpV}$ absence in F. tularensis, contributes to the assembly-disassembly cycle of the T6SS apparatus, and generates the energy required for T6SS [49].

Furthermore, it has been demonstrated that the P. gingivalis clpB null mutant exhibits low invasiveness and attenuated virulence in a murine model of infection [50]. The virulence of Listeria monocytogenes, Salmonella typhimurium and Mycobacterium tuberculosis clpB null mutants was also significantly attenuated in the infection models, as compared to the wild-type and complemented strains [44,51,52]. Additionally, in the case of $M$. tuberculosis, it has been shown that $\mathrm{ClpB}$ is an important mediator of resistance against proteotoxic stress caused by the sequestration of IOPs (irreversibly oxidized proteins) and followed by the asymmetric distribution of aggregates within bacteria and between their progeny [52]. Thanks to such a distribution of aggregated proteins, some bacterial progeny contain a minimal amount of IOPs and cope with stressful conditions much more efficiently than their IOP-burdened siblings. Furthermore, $\mathrm{ClpB}$ is required for induced thermotolerance of L. monocytogenes and Enterococcus faecalis [44,53]. The E. faecalis clpB null strain also showed a reduced virulence in the Galleria mellonella infection model [53].

A loss of the $\mathrm{ClpB}$ function in the pathogenic spirochaete Leptospira interrogans resulted in bacterial growth defects under stress conditions, such as thermal and oxidative stresses and nutrient limitation [54]. Moreover, it has been shown that the ClpB deficiency made that pathogen avirulent in an animal model of acute leptospirosis (in gerbils), as compared to its parental strain [54]. The role and significance of ClpB in leptospiral virulence and pathogenesis of leptospirosis was discussed in detail in a recent review [43]. Briefly, recent results [55] indicated that the $\mathrm{ClpB}$-mediated protein disaggregation activity is responsible for maintaining energy homeostasis under stress conditions in L. interrogans by protecting the conformational integrity and catalytic activity of metabolic enzymes, which are sensitive to stress and prone to aggregation. Thus, it could be proposed that $\mathrm{ClpB}$ plays an important role in the L. interrogans stress-induced adaptation to mammalian hosts. Notably, ClpB is one of the L. interrogans hub proteins interacting with the host factors, including the components of ECM (extracellular matrix) and the host plasma [56]. Furthermore, it is also likely that $L$. interrogans $\mathrm{ClpB}$ is involved in evading the toll-like receptor responses. Taken together, the previous results suggest that $\mathrm{ClpB}$ may be involved in the adhesion of Leptospira to the surface of host cells, plasminogen acquisition, and the immune evasion. Certainly, further studies are needed to fully resolve the role of $\mathrm{ClpB}$ in leptospiral virulence and the pathogenesis of leptospirosis, a zoonotic disease with a significant impact on public health worldwide.

Recently, the role of $\mathrm{ClpB}$ in Mycobacterium tuberculosis has been also investigated in more detail [13]. It has been demonstrated that $\mathrm{ClpB}$ is required for the survival of $M$. tuberculosis under stressful conditions and is involved in regulating its virulence. Additionally, the same study found that $\mathrm{ClpB}$ is necessary for the maintenance of dormant $M$. tuberculosis in latency-like conditions, such as prolonged hypoxia and nutrient starvation [13]. Such conditions exist inside granulomas that form during the host's immune response to $M$. tuberculosis. The tuberculosis granulomas create not only an immune microenvironment for controlling the infection, but also provide a niche in which mycobacteria can survive in a dormant state [57]. Since, dormancy ensures the survival of mycobacteria inside hypoxic granulomas, $\mathrm{ClpB}$ may be one of the key players in maintaining the persistence of $M$. tuberculosis within its host. Interestingly, it is also possible that $\mathrm{ClpB}$, together with its DnaK partner, contribute to a recovery from dormancy and restoration of mycobacterial cell activity [58], which occurs in 10\% of the latently infected individuals [57]. Therefore, it is likely that $\mathrm{ClpB}$ also supports an escape strategy of mycobacteria from granulomas and their spread throughout the body, which results in disease progression [57]. Furthermore, it has been shown for the first time that some fraction of $\mathrm{ClpB}$, a cytosolic protein, can 
be secreted into the extracellular environment and can interact with host macrophages. Hence, $\mathrm{ClpB}$ mediates the inflammatory immune response which may help in maintaining the integrity of tuberculous granulomas containing the pathogen [13]. Taken together, the studies described above have revealed that $\mathrm{ClpB}$ acts not only as a stress-response factor in pathogenic bacteria, but it may also function as a signaling molecule.

$\mathrm{ClpB}$ is also required for in-host survival of Mycoplasma pneumoniae, the smallest self-replicating microorganism [59]. Moreover, it was demonstrated that $\mathrm{ClpB}$ can elicit an immune response in experimentally infected mice and patients infected with M. pneumoniae, again, highlighting its role in the M. pneumoniae virulence. ClpB-mediated activation of the host's immune response was also found during infections with L. interrogans and $F$. tularensis $[60,61]$. The documented secretion of $M$. tuberculosis $\mathrm{ClpB}$ into the extracellular environment [13] may explain an apparent immunogenicity of $\mathrm{ClpB}$ from pathogenic bacteria. Finally, it has been found that in Ehrlichia chaffeensis, during infection of mammalian cells, the $c l p B$ expression is elevated and its induction correlates with the pathogen's replicating stage inside host cells, which demonstrates an essential role of ClpB in the Ehrlichia response to the host-induced stress [20].

A number of studies described above have collectively demonstrated an essential role of $\mathrm{ClpB}$ in host invasion and the rapid adaptation of bacterial pathogens to their hosts, pathogen survival and replication, and evasion of the host defense mechanisms. Thus, ClpB performs multiple functions in bacterial pathogens (Figure 3). As described above, the biochemical activity of $\mathrm{ClpB}$ as an energy-dependent disaggregase, has been well documented. A link between infection and the aggregation propensity of the pathogen's proteins has only begun to emerge $[62,63]$. It needs to be determined if protein aggregation is a universal factor that affects the pathogens' survival in infected hosts and how the disaggregase activity of $\mathrm{ClpB}$ supports the various adaptive processes that help establish bacterial infections.

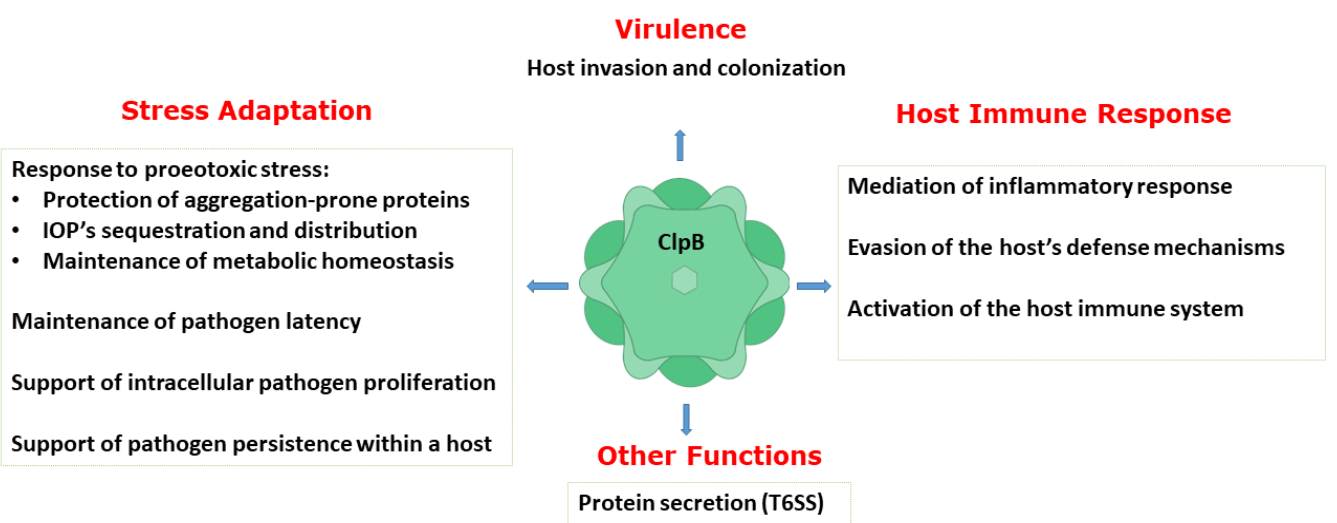

Figure 3. Summary of the documented functions of $\mathrm{ClpB}$ in supporting virulence, host-pathogen interactions, and stress adaptation in pathogenic bacteria. IOPs: irreversibly oxidized proteins; T6SS: type VI secretion system.

\section{ClpB as a Druggable Target}

The absence of $\mathrm{ClpB}$ orthologs in mammals, including humans, makes this chaperone an attractive target in combating bacterial infections. As described above, $\mathrm{ClpB}$ is an essential factor in bacterial stress response and pathogen virulence. Thus, inhibition of $\mathrm{ClpB}$ might suppress infectivity and the survival of invading pathogens. However, selective and high-affinity inhibitors of $\mathrm{ClpB}$ are not currently available.

Studies on the Hsp104-supported propagation of yeast prions identified millimolarrange guanidinium chloride $(\mathrm{GdmHCl})$ as a surprisingly effective and selective inhibitor of Hsp104 [64]. A millimolar concentration of $\mathrm{GdmHCl}$ is insufficient to induce protein denaturation, but it inhibits the ATPase activity of ClpB/Hsp104 in vitro and impairs thermotolerance in bacteria and yeast $[15,65,66]$. A crystal structure of NBD-1 from Thermus thermophilus $\mathrm{ClpB}$ in the presence of $\mathrm{ADP}$ and $\mathrm{GdmHCl}$ revealed that the guanidinium 
cation binds in close proximity to the nucleotide, directly above the adenine ring and the $2^{\prime}-\mathrm{OH}$ of ribose [67]. Biochemical studies showed the inhibitory effect of $\mathrm{Gdm}^{+}$to arise from the stabilization of the ClpB-nucleotide complex and the reduction of the nucleotide dissociation rate [67].

Weak binding affinity $\left(K_{\text {diss }} \approx 1 \mathrm{mM}\right)$ and possible off-target effects make $\mathrm{GdmHCl}$ unsuitable for further development as a drug candidate. However, $\mathrm{GdmHCl}$ became a useful tool to probe the biological function of $\mathrm{ClpB}$ in pathogenic bacteria. For instance, the ATPase activity of ClpB from the tick-transmitted pathogen, Ehrlichia chaffeensis was significantly inhibited in vitro by $1 \mathrm{mM} \mathrm{GdmHCl} \mathrm{[62].} \mathrm{In} \mathrm{a} \mathrm{culture} \mathrm{of} \mathrm{Ehrlichia-infected}$ macrophages, pathogen viability was reduced by $\sim 60 \%$ in the presence of $0.5 \mathrm{mM} \mathrm{GdmHCl}$ without affecting host cells. Furthermore, the size of the aggregated protein fraction in E. chaffeensis increased significantly in cultures supplemented with $0.5 \mathrm{mM} \mathrm{GdmHCl}$, which also resulted in preferential accumulation of $\mathrm{ClpB}$ with the aggregated proteins [62], consistent with trapping of chaperone-aggregate complexes due to slow ATP turnover.

Several groups performed unbiased screens of chemical libraries in search for other ClpB inhibitor leads. A high-throughput screen for ClpB-interacting compounds [68] identified several $\mathrm{ClpB}$ ligands that unfortunately belong to the promiscuous "pan assay interference compounds" ("PAINS") [69] and the remaining promising compounds exhibited off-target effects. Another screen identified suramin as a ligand for Hsp100 [70]; however, suramin is a known promiscuous inhibitor of many ATP-binding proteins [71,72]. Consequently, no ClpB inhibitor has been identified so far by unbiased screens that might represent a promising lead for drug development.

A recent study explored the hypothesis that known small-molecule ligands of AAA+ ATPases might also interact with ClpB. Among three inhibitors of the human AAA+ ATPase p97, a promising antitumor target, only one affected ClpB [73]. The identified compound, $\mathrm{N}^{2}, \mathrm{~N}^{4}$-dibenzylquinazoline-2,4-diamine ( $\mathrm{DBeQ}$ ) has been previously used as an antimicrobial $[74,75]$, but without clear identification of its cellular targets. It has now been shown that $\mathrm{ClpB}$ is the main target of $\mathrm{DBeQ}$ in $E$. coli under both permissive conditions and during heat stress [73]. Thus, $\mathrm{ClpB}$ can be selectively targeted with a small-molecule ligand in bacterial cells and such a treatment could produce a loss of bacterial viability. Interestingly, targeting $\mathrm{ClpB}$ with $\mathrm{DBeQ}$ in $E$. coli cells produced toxicity that transcended a loss-of-function phenotype observed in the $c l p B$-null strain. Toxicity of $\mathrm{ClpB}$ in bacteria and Hsp104 in yeast has been observed before for "hyperactive" protein variants with mutations within the middle domain [76-78]. Whether an analogous toxic gain of function occurs in the DBeQ-treated ClpB remains to be investigated.

\section{Conclusions}

In this review, we highlighted an important role of the Hsp100 chaperone ClpB in supporting the virulence and survival of a broad range of pathogenic bacteria. Multiple studies revealed that the ClpB-mediated protein disaggregation activity plays a key role in the pathogen response to the host-induced proteotoxic stresses. The effectiveness of this response determines the pathogen's ability to adapt to the stress, proliferate in the host cells, and induce disease symptoms. Interestingly, $\mathrm{ClpB}$ may also perform other functions in pathogenic bacteria, which are necessary for their virulence and may be linked to disease (see Figure 3). Importantly, the absence of $\mathrm{ClpB}$ orthologs in humans and its demonstrated druggability make this chaperone a high-priority target for inhibitor development.

Global spread of antibiotic resistance among bacterial pathogens (e.g., methicillinresistant Staphylococcus aureus (MRSA), vancomycin-resistant Enterococcus (VRE) multidrug-resistant Mycobacterium tuberculosis (MDR-TB), carbapenem-resistant Enterobacteriaceae (CRE) gut bacteria) became one of the most serious public health challenges of the twenty-first century. The development of novel antibacterial strategies and the discovery of new antibiotics is crucial for meeting that challenge. Targeting microbial Hsp100 chaperones provides a promising pathway for the development of innovative therapeutic strategies in combating a broad range of infectious diseases. 
Author Contributions: Writing and editing, S.K.-M., M.Z.; visualization, S.K.-M. All authors have read and agreed to the published version of the manuscript.

Funding: This work was supported by the University of Gdańsk (grant no. DS-531/D010-D241-21; S.K.-M.) and the National Institutes of Health (grant no. AI141586; M.Z.).

Institutional Review Board Statement: Not applicable.

Informed Consent Statement: Not applicable.

Data Availability Statement: Not applicable.

Acknowledgments: We are very grateful to Anita Winiarska, student of the 2nd MSU at the Faculty of Biology of the University of Gdańsk, for her invaluable help in preparing Figures 2 and 3.

Conflicts of Interest: The authors declare no conflict of interest.

\section{References}

1. Vouga, M.; Greub, G. Emerging bacterial pathogens: The past and beyond. Clin. Microbiol. Infect. 2016, 22, 12-21. [CrossRef] [PubMed]

2. Thakur, A.; Mikkelson, H.; Jurgersen, G. Intracellular pathogens: Host immunity and microbial persistence strategies. J. Immunol. Res. 2019, 2019, 1-24. [CrossRef] [PubMed]

3. Doron, S.; Gorbach, S.L. Bacterial infections: Overview. Int. Encycl. Public Health 2008, $273-282$.

4. Cantas, L.; Suer, K. Review: The important bacterial zoonoses in "One Health" concept. Front. Public Health 2014, 2, 144. [CrossRef]

5. Tomley, F.M.; Shirley, M.W. Livestock infectious diseases and zoonoses. Philos. Trans. R. Soc. B 2009, 364, 2637-2642. [CrossRef]

6. Jones, B.A.; Grace, D.; Kock, R.; Alonso, S.; Rushton, J.; Said, M.Y.; McKeever, D.; Mutua, F.; Young, J.; McDermott, J.; et al. Zoonosis emergence linked to agricultural intensification and environmental change. Proc. Natl. Acad. Sci. USA 2013, 10, 8399-8404. [CrossRef] [PubMed]

7. Albiger, B.; Dahlberg, S.; Henriques-Normark, B.; Normark, S. Role of the innate immune system in host defence against bacterial infections: Focus on the Toll-like receptors. J. Intern. Med. 2007, 261, 511-528. [CrossRef]

8. Frieri, M.; Kumar, K.; Boutin, A. Antibiotic resistance. J. Infect. Public Health 2017, 10, 369-378. [CrossRef]

9. Chattopadhyay, M.K.; Chakraborty, R.; Grossart, H.-P.; Reddy, G.S.; Jagannadham, M.V. Antibiotic resistance of bacteria. Biomed. Res. Int. 2015, 2015, 501658. [CrossRef]

10. Neuwald, A.F.; Aravind, I.; Spouge, J.L.; Koonin, E.V. AAA+: A class of chaperone-like ATPases associated with the assembly, operation, and disassembly of protein complex. Genome Res. 1999, 9, $27-43$.

11. Hanson, P.I.; Whiteheart, S.W. AAA+ proteins: Have engine, will work. Nat. Rev. Mol. Cell Biol. 2005, 6, 519-529. [CrossRef] [PubMed]

12. Katikaridis, P.; Meins, L.; Kamal, S.M.; Römling, U.; Mogk, A. ClpG provides increased heat resistance by acting as superior disaggregase. Biomolecules 2019, 9, 815. [CrossRef] [PubMed]

13. Tripathi, P.; Singh, L.K.; Kumari, S.; Hakiem, O.R.; Batra, J.K. ClpB is an essential regulator of Mycobacterium tuberculosis and endows survival advantage to dormant bacilli. Int. J. Med. Microbiol. 2020, 310, 151402. [CrossRef] [PubMed]

14. Squires, C.L.; Pedersen, S.; Ross, B.M.; Squires, C. ClpB is the Escherichia coli heat shock protein F84.1. J. Bacteriol. 1991, 173, 4254-4262. [CrossRef]

15. Zolkiewski, M. ClpB cooperates with DnaK, DnaJ, and GrpE in suppressing protein aggregation. J. Biol. Chem. 1999, 274, 28083-28086. [CrossRef]

16. Goloubinoff, P.; Mogk, A.; Ben-Zvi, A.P.; Tomoyasu, T.; Bukau, B. Sequential mechanism of solubilization and refolding of stable protein aggregates by a bichaperone network. Proc. Natl. Acad. Sci. USA 1999, 96, 13732-13737. [CrossRef] [PubMed]

17. Mogk, A.; Tomoyasu, T.; Goloubinoff, P.; Rúdiger, S.; Röder, D.; Langen, H.; Bukau, B. Identification of thermolabile Escherichia coli proteins: Prevention and reversion of aggregation by DnaK and ClpB. EMBO J. 1999, 18, 6934-6949. [CrossRef]

18. Zolkiewski, M.; Zhang, T.; Nagy, M. Aggregate reactivation mediated by the Hsp100 chaperones. Arch. Biochem. Biophys. 2012, 520, 1-6. [CrossRef] [PubMed]

19. Doyle, S.M.; Hoskins, J.R.; Wicker, S. Collaboration between the ClpB AAA+ remodeling protein and the DnaK chaperone system. Proc. Natl. Acad. Sci. USA 2007, 104, 11138-11144. [CrossRef]

20. Zhang, T.; Kędzierska-Mieszkowska, S.; Liu, H.; Cheng, C.; Ganta, R.R.; Zolkiewski, M. Aggregate-reactivation activity of the molecular chaperone ClpB from Ehrlichia chaffeensis. PLoS ONE 2013, 8, e62454. [CrossRef]

21. Krajewska, J.; Modrak-Wójcik, A.; Arent, Z.; Więckowski, D.; Zolkiewski, M.; Bzowska, A.; Kędzierska-Mieszkowska, S. Characterization of the molecular chaperone ClpB from the pathogenic spirochaete Leptospira interrogans. PLoS ONE 2017, 12, e0181118. [CrossRef]

22. Schlee, S.; Beinker, P.; Akhrymuk, A.; Reinstein, J. A chaperone network for the resolubilization of protein aggregates: Direct interaction of ClpB and DnaK. J. Mol. Biol. 2004, 336, 275-285. [CrossRef] 
23. Miot, M.; Reidy, M.; Doyle, S.M.; Hoskins, J.R.; Johnston, D.M.; Genest, D.; Vitery, M.C.; Massion, D.C.; Wicker, S. Species-specific collaboration of heat shock proteins (Hsp) 70 and 100 in thermotolerance and protein disaggregation. Proc. Natl. Acad. Sci. USA 2011, 108, 6915-6920. [CrossRef]

24. DeSantis, M.E.; Shorter, J. The elusive middle domain of Hsp104 and ClpB: Location and function. Biochim. Biophys. Acta 2012, 1823, 29-39. [CrossRef]

25. Lee, S.; Sowa, M.E.; Watanabe, Y.; Sigler, P.B.; Chiu, W.; Yoshida, M.; Tsai, F.T. The structure of ClpB: A molecular chaperone that rescues proteins from an aggregated state. Cell 2003, 115, 229-240. [CrossRef]

26. Zolkiewski, M.; Kessel, M.; Ginsburg, A.; Maurizi, M.R. Nucleotide-dependent oligomerization of ClpB from Escherichia coli. Protein Sci. 1999, 8, 1899-1903. [CrossRef]

27. Akoev, V.; Gogol, E.P.; Barnett, M.E.; Zolkiewski, M. Nucleotide-induced switch in oligomerization of the AAA+ ATPase ClpB. Protein Sci. 2004, 13, 567-574. [CrossRef]

28. Lin, J.; Lucius, A.L. Examination of the dynamic assembly equilibrium for E. coli ClpB. Proteins 2015, 83, 2008-2024. [CrossRef]

29. Kedzierska, S.; Akoev, V.; Barnett, M.E.; Zolkiewski, M.M. Structure and function of the middle domain of ClpB from Escherichia coli. Biochemistry 2003, 42, 14242-14248. [CrossRef]

30. Lee, S.; Roh, S.H.; Lee, J.; Sung, N.; Liu, J.; Tsai, F.T.F. Cryo-EM structures of the Hsp104 protein disaggregase captured in the ATP conformation. Cell Rep. 2019, 26, 29-36. [CrossRef]

31. Weibezahn, J.; Tessarz, P.; Schlieker, C.; Zahn, R.; Maglica, Z.; Lee, S.; Zentgraf, H.; Weber-Ban, E.U.; Dougan, D.A.; Tsai, F.T.; et al. Thermotolerance requires refolding of aggregated proteins by substrate translocation through the central pore of ClpB. Cell 2004, 119, 653-665. [CrossRef]

32. Gates, S.N.; Yokom, A.L.; Lin, J.; Jackrel, M.E.; Rizo, A.N.; Kendsersky, N.M.; Buell, C.E.; Sweeny, E.A.; Mack, K.L.; Chuang, E.; et al. Rachet-like polypeptide translocation mechanism of the AAA+ disaggregase Hsp104. Science 2017, 357, 273-279. [CrossRef] [PubMed]

33. Yu, H.; Lupoli, T.J.; Kovach, A.; Meng, X.; Zhao, G.; Nathan, C.F.; Li, H. ATP hydrolysis-coupled peptide translocation mechanism of Mycobacterium tuberculosis ClpB. Proc. Natl. Acad. Sci. USA 2018, 115, E9560-E9569. [CrossRef] [PubMed]

34. Rizo, A.N.; Lin, J.; Gates, S.N.; Tse, E.; Bart, S.M.; Castellano, L.M.; DiMaio, F.; Shorter, J.; Southworth, D.R. Structural basis for substrate gripping and translocation by the ClpB AAA+ disaggregase. Nat. Commun. 2019, 10, 2393. [CrossRef] [PubMed]

35. Avellaneda, M.J.; Franke, K.B.; Sunderlikova, V.; Bukau, B.; Mogk, A.; Trans, S.J. Processive extrusion of polypeptide loops by a Hsp100 disaggregase. Nature 2020, 578, 317-320. [CrossRef]

36. De Los Rios, P.; Ben-Zvi, A.; Slutsky, O.; Azem, A.; Goloubinoff, B. Hsp70 chaperones accelerate protein translocation and the unfolding of stable protein aggregates by entropic pulling. Proc. Natl. Acad. Sci. USA 2006, 103, 6166-6171. [CrossRef]

37. Wentink, A.S.; Nillegoda, N.B.; Feufel, J.; Ubartaite, G.; Schneider, C.P.; De Los Rios, P.; Hennig, J.; Barducci, A.; Bukau, B. Molecular dissection of amyloid disaggregation by human Hsp70. Nature 2020, 587, 483-488. [CrossRef]

38. Erives, A.J.; Fassler, J.S. Metabolic and chaperone gene loss marks the origin of animals: Evidence for hsp104 and Hsp78 chaperones sharing mitochondrial enzymes as clients. PLoS ONE 2015, 10, e0117192. [CrossRef]

39. Capestany, C.A.; Tribble, G.D.; Maeda, K.; Demuth, D.R.; Lamont, R.J. Role of the ClpB system in stress tolerance, biofilm formation, and intracellular invasion in Porphyromonas gingivalis. J. Bacteriol. 2008, 190, 1436-1446. [CrossRef]

40. Frees, D.; Chastanet, A.; Qazi, S.; Serensen, K.; Hill, P.; Msadek, T.; Ingmer, H. Clp ATPases are required for stress tolerance, intracellular replication and biofilm formation in Staphylococcus aureus. Mol. Microbiol. 2004, 54, 1445-1462. [CrossRef]

41. van Steenbergen, T.J.M.; Petit, M.D.A.; Scholte, L.H.M.; van der Velden, U.; de Graff, J. Transmission of Porphyromonas gingivalis between spouses. J. Clin. Periodontol. 1993, 20, 340-345. [CrossRef]

42. Adhikari, K.; Saimbi, C.S.; Gupta, B.P. Estimation of Porphyromonas gingivalis from mother to child through saliva. J. Nepal. Med. Assoc. 2018, 56, 781-786. [CrossRef]

43. Kędzierska-Mieszkowska, S.; Arent, Z. AAA+ molecular chaperone ClpB in Leptospira interrogans: Its role and significance in leptospiral virulence and pathogenesis of leptospirosis. Int. J. Mol. Sci. 2020, 21, 6645. [CrossRef]

44. Chastanet, A.; Derre, I.; Nair, S.; Msadek, T. $\operatorname{clpB}$, a novel number of the Listeria monocytogenes CtsR regulon, is involved in virulence but not in general stress tolerance. J. Bacteriol. 2004, 186, 1165-1174. [CrossRef] [PubMed]

45. Higuita, N.I.A.; Huycke, M.M. Enterococcal disease, epidemiology, and implications for treatment. In Enterococci: From Commensals to Leading Causes of Drug Resistant Infection; Gilmore, M.S., Clewell, D.B., Ike, Y., Shanker, N., Eds.; Massachusetss Eye and Ear Infirmary: Boston, MA, USA, 2014.

46. Nigrovic, L.E.; Wingerter, S.L. Tularemia. Infect. Dis. Clin. N. Am. 2008, 22, 489-504. [CrossRef] [PubMed]

47. Hendriksen, S.W.M.; Orsel, K.; Wagenaar, J.A.; Miko, A.; van Duijkeren, E. Animal-to human transmission of Salmonella typhimurium DT104A variant. Emerg. Infect. Dis. 2004, 10, 2225-2227. [CrossRef]

48. Meibom, K.L.; Dubail, I.; Dupuis, M.; Barel, M.; Lenco, J.; Stulik, J.; Golovliov, I.; Sjöstedt, A.; Charbit, A. The heat shock protein $\mathrm{ClpB}$ of Francisella tularensis is involved in stress tolerance and is required for multiplication in target organs of infected mice. Mol. Microbiol. 2008, 67, 1384-1401. [CrossRef]

49. Alam, A.; Golovliov, I.; Javed, E.; Sjöstedt, A. ClpB mutants of Francisella tularensis subspecies holartica and tularensis are defective for type VI secretion and intracellular replication. Sci. Rep. 2018, 8, 11324. [CrossRef] [PubMed]

50. Yuan, L.; Rodriques, P.H.; Belanger, M.; Dunn, W., Jr.; Progulske-Fox, A. The Porphyromonas gingivalis clpB gene is involved in cellular invasion In Vitro and virulence In Vivo. FEMS Immunol. Med. Microbiol. 2007, 51, 388-398. [CrossRef] [PubMed] 
51. Turner, A.K.; Lovell, M.A.; Hulme, S.D.; Zhang-Barber, L.; Barrow, P. Identification of Salmonella typhimurium genes required for colonization of the chickem alimentary tract and for virulence in newly hatched chicks. Intect. Immun. 1998, 66, 2099-2106. [CrossRef] [PubMed]

52. Vaubourgeix, J.; Lin, G.; Dhar, N.; Chenouard, N.; Jiang, X.; Botella, H.; Lupoli, T.; Mariani, O.; Yang, G.; Ouerfelli, O.; et al. Stressed mycobacteria use the chaperone $\mathrm{ClpB}$ to sequester irreversibly oxidized proteins asymmetrically within and between cells. Cell Host Microbe 2015, 17, 178-190. [CrossRef]

53. de Oliveira, N.E.M.; Abranches, J.; Gaca, A.O.; Laport, M.S.; Damaso, C.R.; Bastos, M.C.; Lemos, J.A.; Giambiagi-deMarval, M. $\operatorname{clpB}$, a class III heat-shock gene regulated by CtsR, is involved in thermotolerane and virulence of Enterococcus faecalis. Microbiology 2011, 157, 656-665. [CrossRef]

54. Lourdault, K.; Cerqueira, G.M.; Wunder, E.A., Jr.; Picardeau, M. Inactivation of $c l p B$ in the pathogen Leptospira interrogans reduces virulence and resistance to stress conditions. Infect. Immun. 2011, 79, 3711-3717. [CrossRef]

55. Krajewska, J.; Arent, Z.; Zolkiewski, M.; Kędzierska-Mieszkowska, S. Isolation and identification of putative protein substrates of the AAA+ molecular chaperone ClpB from the pathogenic spirochaete Leptospira interrogans. Int. J. Mol. Sci. 2018, 19, 1234. [CrossRef] [PubMed]

56. Kumar, S.; Lata, K.S.; Sharma, P.; Bhairappanavar, S.B.; Soni, S.; Das, J. Inferring pathogen-host interactions between Leptospira interrogans and Homo sapiens using network theory. Sci. Rep. 2019, 9, 1434. [CrossRef] [PubMed]

57. Miranda, M.S.; Breiman, A.; Allain, S.; Deknuydt, F.; Altare, F. The tuberculosis granuloma: A unsuccessful host defence mechanism providing a safety shelter for the bacteria? J. Immunol. Res. 2012, 2012, 139127. [CrossRef]

58. Pu, Y.; Li, Y.; Jin, X.; Leake, M.C.; Lo, C.-J.; Bai, F. ATP-dependent dynamic protein aggregation regulates bacterial dormancy depth critical for antibiotic tolerance. Mol. Cell 2019, 73, 143-158. [CrossRef] [PubMed]

59. Kannan, T.R.; Musatovova, O.; Gowda, P.; Baseman, J.B. Characterization of a unique ClpB protein of Mycoplasma pneumoniae and its impact on growth. Infect. Immun. 2008, 76, 5082-5092. [CrossRef]

60. Krajewska, J.; Arent, Z.; Więckowski, D.; Zolkiewski, M.; Kędzierska-Mieszkowska, S. Immunoreactivity of the AAA+ chaperone ClpB from Leptospira interrogans with sera from Leptospira-infected animals. BMC Microbiol. 2016, 16, 151-158. [CrossRef]

61. Barrigan, L.M.; Tuladhar, S.; Brunton, J.C.; Woolard, M.D.; Chen, C.; Saini, D.; Frothingham, R.; Sempowski, G.D.; Kawula, T.H.; Frelinger, J.A. Infection with Francisella tularensis LVS clpB leads to an altered yet protective immune response. Infect. Immun. 2013, 81, 2028-2042. [CrossRef] [PubMed]

62. Kuczyńska-Wisnik, D.; Cheng, C.; Ganta, R.R.; Zolkiewski, M. Protein aggregation in Ehrlichia chaffeensis during infection of mammalian Wells. FEMS Microbiol. Lett. 2017, 364, 1-5. [CrossRef]

63. Dong, S.; Hu, W.; Me, Y.; Ojcius, D.M.; Lin, X.; Yan, J. A leptospiral AAA+ chaperone-Ntn peptidase complex, HslUV, contributes to the intracellular survival of Leptospira interrogans in hosts and the transmission of leptospirosis. Emerg. Microbes Infect. 2017, 6, e105. [CrossRef] [PubMed]

64. Jung, G.; Masison, D.C. Guanidine hydrochloride inhibits Hsp104 activity In Vivo: A possible explanation for its effect in curing yeast prions. Curr. Microbiol. 2001, 43, 7-10. [CrossRef]

65. Grimminger, V.; Richter, K.; Imhof, A.; Buchner, J.; Walter, S. The prion curing agent guanidinum chloride specifically inhibits ATP hydrolysis by Hsp104. J. Biol. Chem. 2004, 279, 7378-7383. [CrossRef] [PubMed]

66. Nowicki, Ł.; Leźnicki, P.; Morawiec, E.; Litwińczuk, N.; Liberek, K. Role of a conserved aspartic acid in nucleotide binding domain 1 (NBD1) of Hsp100 chaperones in their activities. Cell Stress Chaperones 2012, 17, 361-373. [CrossRef]

67. Zeymer, C.; Werbeck, N.D.; Schlichting, I.; Reinstein, J. The molecular mechanism of Hsp100 chaperone inhibition by the prion curing agent guanidinum chloride. J. Biol. Chem. 2013, 288, 7065-7076. [CrossRef]

68. Martin, I.; Underhaug, J.; Celaya, G.; Moro, F.; Teigen, K.; Martinez, A.; Muga, A. Screening and evaluation of small organic molecules as ClpB inhibitors and potential antimicrobials. J. Med. Chem. 2012, 56, 7177-7189. [CrossRef]

69. Baell, J.; Walters, M.A. Chemistry: Chemical con artists foil drug discovery. Nature 2014, 25, 481-483. [CrossRef]

70. Torrente, M.P.; Castellano, L.M.; Shorter, J. Suramin inhibits Hsp104 ATPase and disaggregase activity. PLoS ONE 2014, 9, e110115. [CrossRef]

71. Stein, A. Suramin: A novel antineoplastic agent with multiple potential mechanisms of action. Cancer Res. 1993, 53, $2239-2248$.

72. Morgan, H.P.; McNae, I.W.; Nowicki, M.W.; Zhong, W.; Michels, P.A.; Auld, D.S.; Fothergill-Gilmore, L.A.; Walkinshaw, M.D. The trypanocidal drug suramin and other trypan blue mimetics are inhibitors of pyruvate kinases and bind to the adenosine site. $J$. Biol. Chem. 2011, 286, 31232-31240. [CrossRef] [PubMed]

73. Glaza, P.; Ranaweera, C.B.; Shiva, S.; Roy, A.; Geisbrecht, B.V.; Schoenen, F.J.; Zolkiewski, M. Repurposing p97 inhibitors for chemical modulation of the bacterial ClpB-DnaK bichaperone system. J. Biol. Chem. 2020, 296, 100079. [CrossRef] [PubMed]

74. DeGraw, J.I.; Brown, V.H.; Colwell, W.T. Potential antileprotic agents. 3. inhibition of mycobacterial dihydrofolic reductase by 2,4-diamino-5-methyl-6-alkylquinazolines. J. Med. Chem. 1974, 17, 762-764. [CrossRef]

75. Van Horn, K.S.; Burda, W.N.; Fleeman, R.; Shaw, L.N.; Manetsch, R. Antibacterial activity of a series of $N^{2}, N^{4}$-disubstituted quinazoline-2,4-diamines. J. Med. Chem. 2014, 57, 3075-3093. [CrossRef] [PubMed]

76. Oguchi, Y.; Kummer, E.; Seyffer, F.; Berynskyy, M.; Anstett, B.; Zahn, R.; Wade, R.C.; Mogk, A.; Bukau, B. A tightly regulated molecular toggle controls AAA+ disaggregase. Nat. Struct. Mol. Biol. 2012, 19, 1338-1346. [CrossRef]

77. Lipińska, N.; Ziętkiewicz, S.; Sobczak, A.; Jurczyk, A.; Potocki, W.; Morawiec, E.; Wawrzycka, A.; Gumowski, K.; Ślusarz, M.; Rodziewicz-Motowidło, S.; et al. Disruption of ionic interactions between the nucleotide binding domain 1 (NBD1) and middle 
(M) domain in Hsp00 disaggregase unleashes toxic hyperactivity and partial independence from Hsp70. J. Biol. Chem. 2013, 288, 2857-2869. [CrossRef]

78. Chamera, T.; Kłosowska, A.; Janta, A.; Wyszkowski, H.; Obuchowski, I.; Gumowski, K.; Liberek, K. Selective Hsp70-dependent docking of Hsp104 to protein aggregates protects the cell from the toxicity of the disaggregase. J. Mol. Biol. 2019, 431, $2180-2196$. [CrossRef] 